\title{
EGFR mutation status in tumour-derived DNA from pleural effusion fluid is a practical basis for predicting the response to gefitinib
}

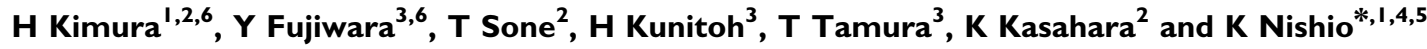 \\ 'Shien-Lab, National Cancer Center Hospital, Tsukiji 5- I, Chuo-ku, Tokyo, Japan; ${ }^{2}$ Respiratory Medicine, Kanazawa University Hospital, Takara-machi I 3- \\ I, Kanazawa, Ishikawa, Japan; ${ }^{3}$ Medical Oncology, National Cancer Center Hospital, Tsukiji 5- I, Chuo-ku, Tokyo, Japan; ${ }^{4}$ Pharmacology Division, National \\ Cancer Center Research Institute, Tsukiji 5-I I, Chuo-ku, Tokyo, Japan; ${ }^{5}$ Center for Medical Genomics, National Cancer Center Research Institute, Tsukiji \\ 5-I-I, Chuo-ku, Tokyo, Japan
}

Epidermal growth factor receptor (EGFR) mutations are strong determinants of tumour response to EGFR tyrosine kinase inhibitors in non-small-cell lung cancer (NSCLC). Pleural effusion is a common complication of lung cancer. In this study, we assessed the feasibility of detection of EGFR mutations in samples of pleural effusion fluid. We obtained 43 samples, which was the cell-free supernatant of pleural fluid, from Japanese NSCLC patients, and examined them for EGFR mutations. The epidermal growth factor receptor mutation status was determined by a direct sequencing method (exons $18-21$ in EGFR). EGFR mutations were detected in II cases (E746_A750del in seven cases, E746_T75I del insA in one case, L747_T75I del in one case, and L858R in two cases). The EGFR mutations were observed more frequently in women and non-smokers. A comparison between the EGFR mutant status and the response to gefitinib in the 27 patients who received gefitinib revealed that all seven patients with partial response and one of the seven patients with stable disease had an EGFR mutation. No EGFR mutations were detected in the patients with progressive disease. The results suggest that DNA in pleural effusion fluid can be used to detect EGFR mutations and that the EGFR mutation status may be useful as a predictor of the response to gefitinib.

British Journal of Cancer (2006) 95, 1390-1395. doi:10.1038/sj.bjc.6603428 www.bjcancer.com

Published online 24 October 2006

(C) 2006 Cancer Research UK

Keywords: pleural effusion; EGFR; mutation; gefitinib

Lung cancer is a major cause of cancer-related mortality worldwide and is expected to remain a major health problem for the foreseeable future (Parkin et al, 2005). Most patients have advanced disease at the time of diagnosis. The initial therapy for advanced non-small-cell lung cancer (NSCLC) is systemic chemotherapy with a two-drug combination regimen, which often includes a platinum agent, but the median survival of patients treated with such regimens has ranged from only 8 to 10 months. Little improvement in the efficacy of chemotherapy has been made in the last 20 years (Breathnach et al, 2001; Kelly et al, 2001; Schiller et al, 2002).

\footnotetext{
*Correspondence: Dr K Nishio, Shien-Lab, National Cancer Center Hospital, Tsukiji 5-I, Chuo-ku, Tokyo, Japan;

E-mail: knishio@gan2.res.ncc.go.jp

Research support: H Kimura received support as an Awardee of a Research Resident Fellowship from the Foundation for Promotion of Cancer Research (Japan) for the 3rd Term Comprehensive 10-Year Strategy for Cancer Control.

${ }^{6}$ These authors contributed equally to this work

Received 13 June 2006; revised 14 September 2006; accepted 15 September 2006; published online 24 October 2006
}

Targeting epidermal growth factor receptor (EGFR) is an appealing strategy for the treatment of NSCLC, because EGFR has been found to be expressed, sometimes strongly, in NSCLC (Franklin et al, 2002). Gefitinib ('Iressa', AstraZeneca) is a small molecule and selective EGFR tyrosine kinase inhibitor that has shown antitumour activity in NSCLC patients as a single agent in phase II trials (Fukuoka et al, 2003). Adding gefitinib to chemotherapy in phase III studies of patients with untreated advanced NSCLC did not significantly improve the outcome over chemotherapy alone (Giaccone et al, 2004; Herbst et al, 2004), and a possible explanation for the failure to observe any added benefit in these trials is that the patients had not been screened or selected for their ability to derive any clinical benefit from an EGFR inhibitor.

An association between mutations in sites of EGFR tyrosine kinase in NSCLC and hyper-responsiveness to gefitinib has recently been reported (Lynch et al, 2004; Paez et al, 2004). The mutations consisted of small in-frame deletions or substitutions clustered around the ATP-binding site in exons 18, 19, and 21 of $E G F R$, and the mutations increased the affinity of the enzyme for ATP and gefitinib (Lynch et al, 2004). Some investigators subsequently found that EGFR mutations are one of the strong determinants of tumour response to EGFR tyrosine kinase inhibitors (Pao et al, 2004; Han et al, 2005). The investigators 
used surgical tissue to detect the EGFR mutations in their studies, but most patients who require gefitinib therapy are diagnosed at an advanced stage of the disease and are inoperable. As it is often difficult to obtain a sufficient tumour sample from patients with inoperable NSCLC to detect EGFR mutations by direct sequencing, a method of detecting EGFR mutations in other specimens needed to be established.

Malignant pleural effusion is a common complication of lung cancer. It is present in approximately $15 \%$ of patients at the time of diagnosis (Pass et al, 2005) and in $10-50 \%$ of patients during the course of the disease (Fenton and David Richardson, 1995). In about half of NSCLC patients with a pleural effusion, the effusion fluid is cytologically positive at the first time examined, and ultimately most effusions are determined to be malignant. As pleural effusion fluid sampling is usually easy, noninvasive, and repeatable, we hypothesised that tumour-derived DNA in the pleural effusion fluid of NSCLC patients would be a source of useful information on the status of the EGFR gene and could allow prediction of the response to gefitinib. Some investigators have reported that pleural effusion fluid is a useful clinical specimen for searching for point mutations in oncogenes, such as K-ras, rho A, p53, and FHIT (Nakamoto et al, 2001; Lee et $a l, 2004)$. As the two trials were small, the results regarding the sensitivity and specificity of detection of the mutations in pleural effusion as a diagnostic method were unclear. Detection of EGFR mutations in pleural effusion fluid has been described in one case report, and the patient responded to gefitinib (Huang et al, 2005). The results in that patient encouraged us to hypothesise that the EGFR mutation status determined in pleural effusion fluid is useful for predicting the responsiveness to EGFR tyrosine kinase inhibitors.

In the present study, we attempted to detect EGFR mutations in pleural effusion fluid and to clarify the usefulness of their detection as a predictor of the response to gefitinib.

\section{PATIENTS AND METHODS}

\section{Patients}

The subjects were NSCLC patients who had a pleural effusion at the time of diagnosis. The diagnosis of NSCLC was based on the histological or cytological findings, and the histological type was determined according to the WHO criteria (Travis et al, 1999). Patients' records consisted of age, gender, smoking habit, histological type, and treatment. Smoking status was collected from the patients' records. Patients were divided into three groups according to their smoking status: never smokers $(<100$ cigarettes/lifetime), former smokers $(\geqslant 100$ cigarettes/ lifetime, no smoking at present), and current smokers $(\geqslant 100$ cigarettes/lifetime). The response of the patients treated with gefitinib was evaluated every 4 or 8 weeks in accordance with the 'Response Evaluation Criteria in Solid Tumours (RECIST)' guidelines. (Therasse et al, 2000). Partial response (PR) and stable disease (SD) were confirmed by a sustained 4 -week follow-up. This study was approved by the Institutional Review Board of the National Cancer Center Hospital and of Kanazawa University Hospital, and written informed consent was obtained from all participants. No research results were entered into the patient's records or released to the patient or the patient's physician.

\section{Collection of pleural effusion fluid and DNA purification}

The pleural effusion fluid was collected into heparinised tubes between 29 March 2005 and 30 January 2006. No particular collection method was used. A 2-ml sample of the fluid was centrifuged at $250 \mathrm{~g}$ for $10 \mathrm{~min}$ at room temperature, and the supernatant was collected and stored at $-80^{\circ} \mathrm{C}$ until DNA extraction. DNA was extracted from $1 \mathrm{ml}$ of the supernatant with a Qiamp DNA Mini Kit (Qiagen, Hilden, Germany) according to the blood and body fluid spin protocol in the manufacturer's instructions, with the following protocol modifications. The same column was used repeatedly until the whole sample had been processed. The DNA obtained was eluted in $50 \mu$ l of sterile bidistilled buffer, and the extracted DNA was stored at $-20^{\circ} \mathrm{C}$ until used. The amounts of DNA extracted were estimated with spectrophotometry.

\section{Polymerase chain reaction amplification and direct sequencing}

Exons 18, 19, 20, and 21 of the EGFR gene were amplified by polymerase chain reaction (PCR). The primers were designed based on the report by Lynch et al (2004). Genomic PCR of $1 \mu \mathrm{l}$ of template DNA was performed in $25 \mu \mathrm{l}$ volumes containing $0.75 \mathrm{U}$ of Ampli Taq Gold DNA polymerase (Perkin-Elmer, Roche Molecular Systems Inc., Branchburg, NJ, USA), $2.5 \mu \mathrm{l}$ of PCR buffer, $0.8 \mu \mathrm{M}$ dNTP, $0.5 \mu \mathrm{M}$ of each primer, and different concentrations of $\mathrm{MgCl}_{2}$, depending on the polymorphic marker. The first PCR analyses were performed in a volume of $25 \mu$ l by 25 cycles consisting of a denaturation step at $94^{\circ} \mathrm{C}$ for $45 \mathrm{~s}$, a primer annealing step at $58^{\circ} \mathrm{C}$ for $30 \mathrm{~s}$, and an elongation step at $72^{\circ} \mathrm{C}$ for $30 \mathrm{~s}$. The final step at $72^{\circ} \mathrm{C}$ was extended for $10 \mathrm{~min}$. Nested PCR was performed with 20 cycles under the same conditions as the first PCR. Sequencing of each sample was performed in duplicate with an ABI prism 310 (Applied Biosystems, Foster City, CA, USA). PCR products were sequenced in both sense and antisense directions. Epidermal growth factor receptor mutations detected in the initial round of sequencing were confirmed by subsequent rounds of independent PCR and sequencing reactions. Only specimens in which a mutation was identified in both rounds were recorded as mutation-positive. The sequences were compared with the GenBank-archived human sequence for EGFR (accession number: AY588246). The nucleic acid and protein coordinates used to name the mutations are based on NM_005228.3 and NP_005219.2, respectively.

\section{Statistical analyses}

This study was carried out as exploratory research for detecting EGFR mutations from pleural effusion fluid and clarifying the relationship between the mutation status and clinical manifestations. The number of enrolled patients was therefore not precalculated. Patient characteristics, including gender, tumour histology, and smoking habit were tabulated according to their mutation status. Fisher's exact test was used to test for associations between the presence of EGFR mutations and the patients' characteristics. The relationship between response to gefitinib and the mutation status was evaluated individually.

\section{RESULTS}

\section{Patients and pleural effusion specimens}

Forty-three patients were enrolled in this study (Table 1). Two hundred and sixty-two patients were seen with stage IIIB and IV at our institutions in the period of this study. Forty-three of the 262 patients were enrolled in this study. The enrolled patients were not all of the patients with pleural effusion because written informed consent was not obtained from any patients with pleural effusion. Their median age was 62 years (range, 39-82 years), and there were 21 females (53.8\%) and 17 never smokers (43.6\%). The histological and/or cytological diagnosis was adenocarcinoma in 39 patients, and squamous cell 
Table I Patient characteristics and EGFR mutation status

\begin{tabular}{|c|c|c|}
\hline & (n) & $\begin{array}{c}\text { EGFR mutation } \\
\text { (n) }\end{array}$ \\
\hline No. of patients & 43 & || (25.6\%) \\
\hline \multicolumn{3}{|l|}{ Age (years) } \\
\hline Median & 63 & \\
\hline Range & $39-82$ & \\
\hline \multicolumn{3}{|l|}{ Gender } \\
\hline Male & 22 & $4(18.2 \%)$ \\
\hline Female & 21 & 7 (33.3\%) \\
\hline \multicolumn{3}{|l|}{ Smoking habit } \\
\hline Current & 9 & $2(22.2 \%)$ \\
\hline Former & 16 & $2(12.5 \%)$ \\
\hline Never & 18 & 7 (38.9\%) \\
\hline \multicolumn{3}{|l|}{ Histology } \\
\hline Adenocarcinoma & 39 & || (28.2\%) \\
\hline Squamous cell carcinoma & । & $0(0 \%)$ \\
\hline Large cell carcinoma & । & $0(0 \%)$ \\
\hline Unclassified & 2 & $0(0 \%)$ \\
\hline No. of patients treated with gefitinib & 27 & $8(29.6 \%)$ \\
\hline PR & 7 & $7(\mid 4.3 \%)$ \\
\hline SD & 7 & । (0\%) \\
\hline PD & 13 & $0(0 \%)$ \\
\hline
\end{tabular}

$\mathrm{EGFR}=$ epidermal growth factor receptor; $\mathrm{PD}=$ progressive disease; $\mathrm{PR}=$ partial response; $\mathrm{SD}=$ stable disease.

carcinoma and large cell carcinoma in one each, and unclassified NSCLC in two patients. Non-small-cell lung cancer cells in the pleural effusion samples of 40 of the patients were identified cytologically. There were no malignant cells in the pleural effusion fluid of the other three patients. We have no data of the proportion of malignant cells and normal cells. Twenty-seven patients were treated with gefitinib $\left(250 \mathrm{mg} \mathrm{day}^{-1}\right)$ and evaluated for a response. Eight of the 27 patients were treated with gefitinib as an initial treatment and the other 19 patients were treated with the agent as a second or third line. The others were treated with systematic chemotherapy, including a platinum agent. The results of the evaluation showed that seven of the 27 patients who received gefitinib therapy had a PR and seven had SD. The other 13 patients had progressive disease (PD). DNA was extracted from all 43 samples of pleural effusion fluid. Amounts of the DNA extracted were detectable from 27 samples at a concentration up to $144.0 \mathrm{ng} \mathrm{ml}^{-1}$. Amounts from 16 samples were under the detectable limit.

\section{Detection of EGFR mutations in pleural effusion fluid}

Direct sequencing of PCR products in exons 18-21 of EGFR in the pleural effusion fluid of all patients allowed their mutation status to be determined. Heterozygous mutations were identified in $11(25.6 \%)$ of the 43 patients (Table 1). Nine mutations were deletional mutations located in exon 19 (E746_A750del in seven, L746_T751del insA in one, L747_T751del in one), and two were substitution mutations located in exon 21 (L858R) (Table 2) (Figure 1). No mutations were detected in exon 18 or 20. The E746_A750 deletion and L858R substitution mutations were the most common (9 out of 11 mutations. $81.8 \%)$ and are well-known hotspot mutations described previously (Kosaka et al, 2004; Pao et al, 2004). No more than one mutation was identified per patient, and no EGFR mutations were detected in pleural effusion fluid that did not contain malignant cells.
Table 2 Site of mutations in exons $|8-2|$ of EGFR

\begin{tabular}{llc}
\hline Nucleotide changes & Amino-acid changes & No. of patients \\
\hline 248I_2495del & E746_A750del & 6 \\
2482_2496del & E746_A750del & $\mid$ \\
2483_2497del & E746_T753del insA & $\mid$ \\
2486_2500del & L747_T75 I del & 2 \\
2819T $>$ G & L858R & I
\end{tabular}

EGFR = epidermal growth factor receptor; del=deletion; ins=insertion. The numbering of the mutation sites was based on NM_005228.3 (nucleotide) and NP_005219.2 (amino acid).

\section{Epidermal growth factor receptor mutation status and patients' characteristics}

EGFR mutations were detected more frequently in the samples from females ( 7 out of $21,33.3 \%$ of females, 4 out of $18,22.2 \%$ of males; $P=0.310$ ) and non-smokers (7 out of $17,41.1 \%$ of nonsmokers, 4 out of $22,18.1 \%$ of current or former smokers; $P=0.156$ ), although the differences were not statistically significant (Table 3). Of the 11 mutations, $63.6 \%$ were in women and $63.6 \%$ were in non-smokers. All of the patients with mutations had adenocarcinoma. No EGFR mutations were found in any of the patients with squamous carcinoma or large cell carcinoma. A comparison between the EGFR mutant status and the response to gefitinib showed that all seven patients with a PR and one of the seven patients with SD had an EGFR mutation. No EGFR mutations were detected in any of the patients with PD (Table 4). We have no response data from the 16 patients who had never treated with gefitinib, and we have not evaluated the relationship between the response to chemotherapy and the EGFR mutation status in pleural effusion fluid.

\section{DISCUSSION}

This is the first report of an analysis of the EGFR mutation status in DNA obtained from the pleural effusion fluid of a series of NSCLC patients and evaluation of the relationship between the mutation status and the clinical response to gefitinib. It is interesting that all patients who achieved a PR to gefitinib had the EGFR mutations. We hypothesised that the mutation status in DNA extracted from pleural effusion fluid would allow prediction of the clinical outcome of gefitinib therapy in NSCLC patients, and we therefore expected the pleural effusion fluid to be a practical source of DNA for detection of EGFR mutations. The sites of EGFR mutations found in this study are identical to these reported in previous studies (Kosaka et al, 2004; Pao et al, 2004). The main mutations found were in-frame deletions in exon 19 and the missense mutation L858R in exon 21. No patients had more than one mutation. It was possible to determine the mutation status of EGFR by using the DNA in only $1.0 \mathrm{ml}$ of pleural effusion fluid, even though the concentration of the extracted DNA specimens was in most cases below the concentration detectable by spectrophotometry (data not shown). The results of the comparison between the mutation status and clinical manifestations in this study confirmed the finding in previous studies that EGFR mutations are frequently present in small sub-groups of NSCLC patients, such as females and never smokers, although the differences were not statistically significant. It is well known that EGFR mutations are frequently observed in adenocarcinomas. As 36 of the 39 patients $(92.3 \%)$ enrolled in this study had adenocarcinoma, we could not evaluate differences in the frequency of the EGFR mutations according to the histological type. Pleural effusion occurs in lung carcinoma of all cell types, but 
Forward
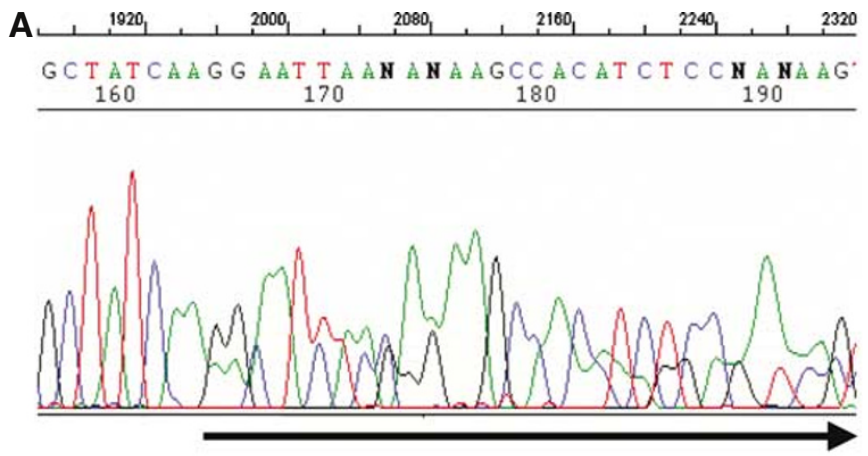

B

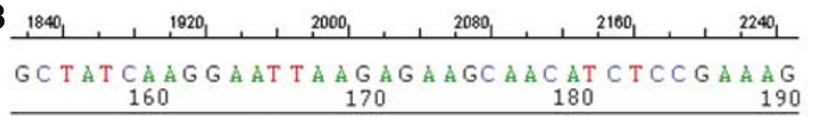
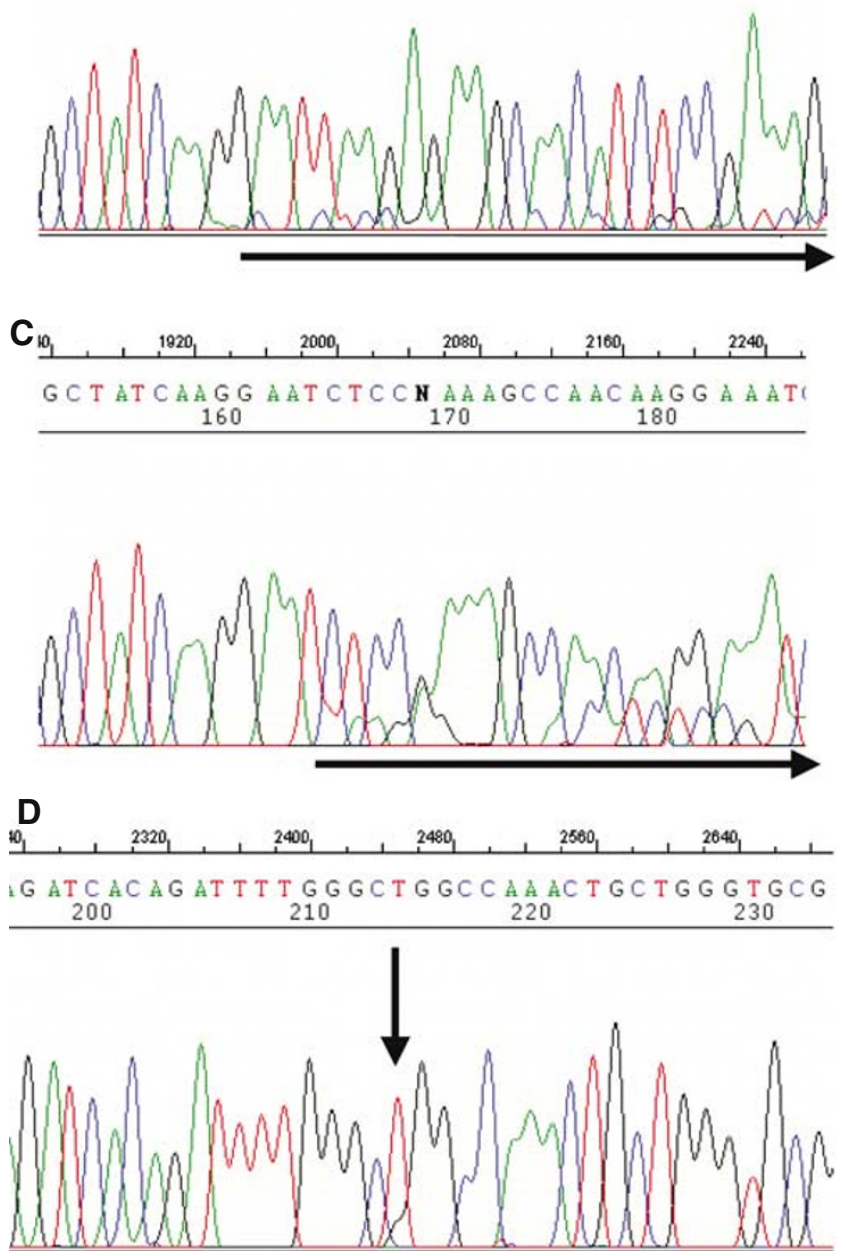

Reverse

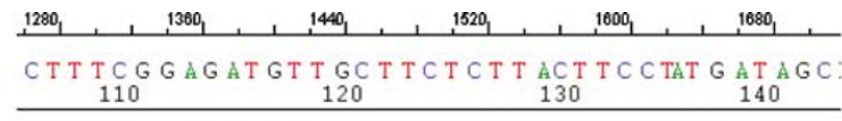
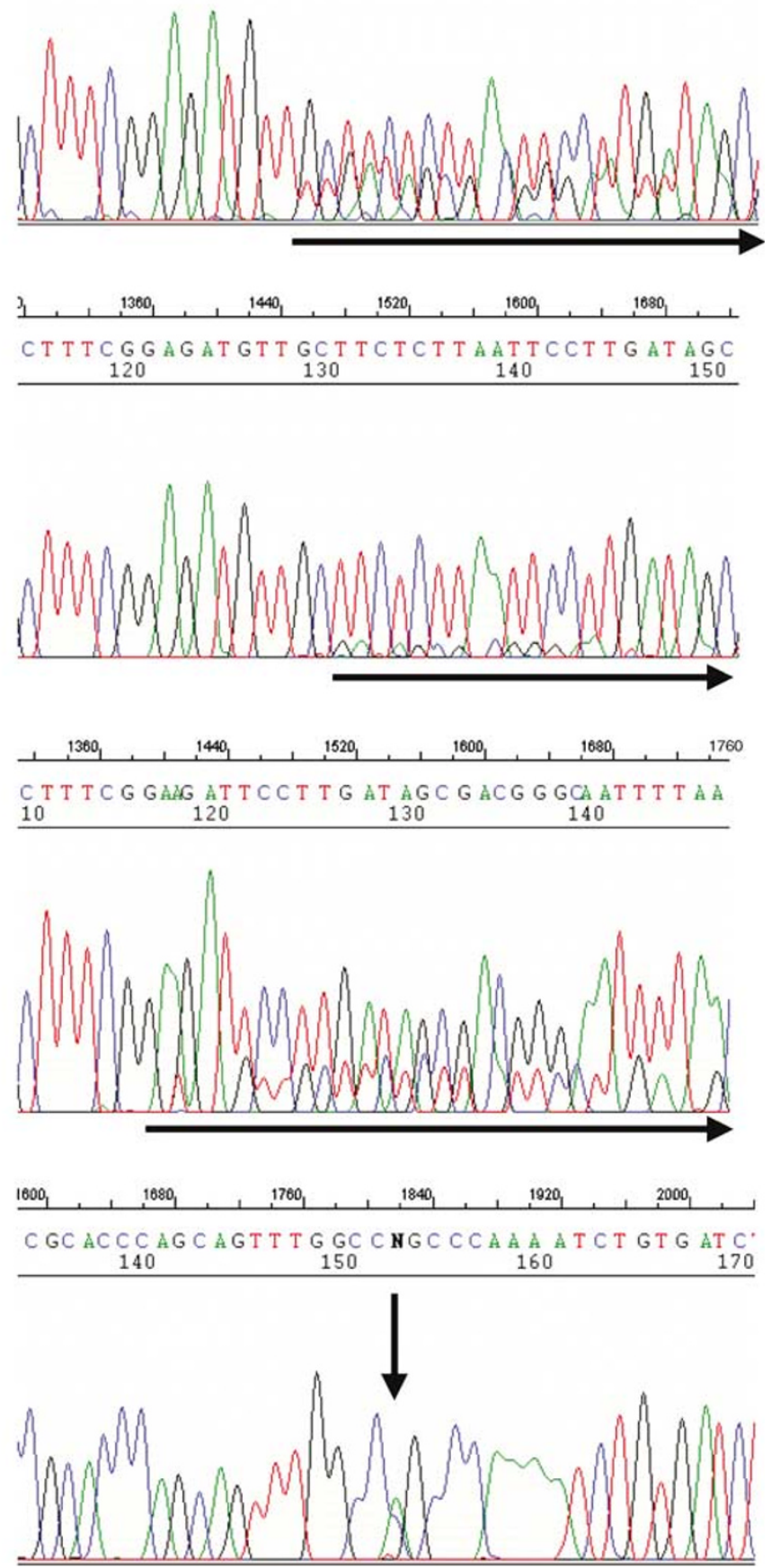

Figure I The wave figures of the nucleotide sequence of the EGFR gene with heterozygous mutations obtained by direct sequencing (see 'Patients and Methods') are shown. Horizontal arrows in both the sense and the antisense directions are shown to demonstrate the two breakpoints of the deletion. The patients in A, B, and $\mathbf{C}$ have inframe deletions in exon 19 (Figure A, E746_A750del; B, E746_T753del insA; C, L747_T75 Idel; D, L858R). The double peaks (vertical arrows) represent the heterozygous missense mutations resulting in an amino acid substitution of L858R in exon 19 (Figure $\mathbf{D}$ ).

appears to be most frequent in adenocarcinoma (Chernow and Shahn, 1997).

This study had several limitations. First, we could not compare the results of the EGFR mutation status in the pleural effusion fluid to the mutation status in tumour tissue. Forty of the 43 patients enrolled were cytologically diagnosed as having NSCLC from pleural effusion fluid specimens. As the DNA extracted from pleural effusion fluid consisted of DNA derived from both tumour cells and normal cells, the EGFR mutation status needs to be evaluated in a pair of DNA specimens from the tumour and pleural 
Table 3 Frequency of EGFR mutations in DNA from the pleural effusion fluid of NSCLC patients according to (A) gender, (B) histology, (C) smoking habit, and (D) response to gefitinib

(A) Gender and EGFR mutation status

EGFR mutation

\begin{tabular}{llll}
\cline { 2 - 4 } & & & \\
& + & - & \\
\hline Female & 7 & 14 & \\
Male & 4 & 18 & $P=0.310$
\end{tabular}

(B) Histology and EGFR mutation status

EGFR mutation

$+\quad-$

\begin{tabular}{lrrr}
\hline Ad & 11 & 28 & \\
Non-Ad & 0 & 4 & $P=0.558$
\end{tabular}

(C) Smoking habit and EGFR mutation status

EGFR mutation

effusion fluid to confirm the usefulness of the mutation status determined from pleural effusion fluid. However, it is sometimes difficult to obtain tumour samples from patients with advanced NSCLC, and even more so from patients diagnosed as having NSCLC using methods other than the histological examination of tumour tissue, such as on the basis of pleural effusion or sputum cytology. Second, direct sequencing may be not able to provide satisfactory results for detection of EGFR mutations in mixed samples of mutated and wild DNA. Although direct sequencing has generally been used to detect EGFR mutations in previous studies, detection of a mutation by this method requires at least $30 \%$ of the mutated DNA in a sample (Bosari et al, 1995; Fan et al, 2001). Lung cancers are very heterogeneous, and as normal cells, such as inflammatory cells or mesothelial cells, are contained in the pleural effusion fluid of lung cancer patients, in addition to tumour cells, a small amount of mutated DNA in pleural effusion fluid can be missed by direct sequencing. Unfortunately, we have no data at the present time on whether EGFR mutations were detectable in pleural effusion samples with either a few malignant cells, a small proportion of malignant cells with normal mesothelial cells, or cytologically negative samples. To establish a method for the detection of EGFR mutations from pleural effusion fluid, the mutation detectable proportion of malignant cells to normal cells in pleural fluid should be elucidated. We are planning an additional study using cytological examination to clarify the mutation detectable proportion as a next step. When pleural fluid is used as the material for detection of EGFR mutations, a patient with an EGFR mutation may be diagnosed as having wild-type EGFR because of the two limitations described above. Although we expected a high frequency of detection of EGFR mutations in this study because of the high proportion of adenocarcinomas (92.3\%), we detected EGFR mutations in only $28.2 \%$ of the patients enrolled, a lower frequency than in two previous reports on Japanese NSCLC patients (Takano et al, 2005; Asano et al, 2006). Patients with false-negative results, meaning that no EGFR mutations were detected in a patient with an EGFR mutation, were not excluded from this study. Some investigators have tried to improve the sensitivity of detection of
Table 4 EGFR mutation status in patients who received gefitinib therapy

\begin{tabular}{|c|c|c|c|c|c|}
\hline $\begin{array}{l}\text { Age } \\
\text { (years) }\end{array}$ & Gender & Smoking & Histology & $\begin{array}{l}\text { EGFR } \\
\text { mutation } \\
\text { status }\end{array}$ & $\begin{array}{l}\text { Response to } \\
\text { gefitinib }\end{array}$ \\
\hline 62 & $\mathrm{~F}$ & Never & $\mathrm{Ad}$ & E747_P753insS & PR \\
\hline 58 & $\mathrm{~F}$ & Never & $\mathrm{Ad}$ & E746_A750del & PR \\
\hline 80 & $\mathrm{~F}$ & Never & Ad & E746_A750del & PR \\
\hline 61 & $M$ & Never & Ad & E746_A750del & PR \\
\hline 65 & M & Former & Ad & E746_A750del & PR \\
\hline 60 & $M$ & Current & Ad & E746_A750del & $P R$ \\
\hline 66 & $\mathrm{~F}$ & Never & Ad & E747_T750del & PR \\
\hline 76 & $\mathrm{~F}$ & Never & $\mathrm{Ad}$ & Wild & SD \\
\hline 57 & $\mathrm{~F}$ & Former & Ad & Wild & SD \\
\hline 40 & $\mathrm{~F}$ & Never & Ad & Wild & SD \\
\hline 72 & $\mathrm{~F}$ & Never & Ad & Wild & SD \\
\hline 58 & $\mathrm{~F}$ & Former & $\mathrm{Ad}$ & Wild & SD \\
\hline 66 & $\mathrm{~F}$ & Never & $\mathrm{Ad}$ & Wild & SD \\
\hline 65 & $\mathrm{~F}$ & Former & Ad & L858R & SD \\
\hline 39 & $\mathrm{~F}$ & Never & Ad & Wild & PD \\
\hline 69 & $M$ & Former & Ad & Wild & $\mathrm{PD}$ \\
\hline 72 & $\mathrm{~F}$ & Never & $\mathrm{Ad}$ & Wild & PD \\
\hline 74 & $\mathrm{~F}$ & Never & Ad & Wild & PD \\
\hline 67 & M & Former & Ad & Wild & PD \\
\hline 62 & M & Former & SCC & Wild & PD \\
\hline 59 & $\mathrm{~F}$ & Current & $\mathrm{Ad}$ & Wild & PD \\
\hline 77 & $M$ & Current & Ad & Wild & PD \\
\hline 82 & $\mathrm{~F}$ & Never & Ad & Wild & PD \\
\hline 66 & $\mathrm{~F}$ & Never & Ad & Wild & PD \\
\hline 56 & M & Current & $\mathrm{Ad}$ & Wild & PD \\
\hline 61 & $M$ & Former & $\mathrm{Ad}$ & Wild & PD \\
\hline 65 & M & Former & Ad & Wild & $\mathrm{PD}$ \\
\hline
\end{tabular}

$A d=$ adenocarcinoma; $E G F R=$ epidermal growth factor receptor; $F=$ female $M=$ male; $N S C L C=$ unclassified $N S C L C ; P D=$ progressive disease; $P R=$ partial response; $\mathrm{SCC}=$ squamous cell carcinoma; $\mathrm{SD}=$ stable disease.

EGFR mutations in samples containing a mixture of tumour and normal cells. Wookey et al (2005) reported findings that the ARMS method was superior to the direct sequencing method and WAVE method for detecting EGFR mutations. Other groups have reported that LightCycler PCR assay (Sasaki et al, 2005), SSCP assay (Marchetti et al, 2005), and enriched PCR assay (Asano et al) are more sensitive than direct sequencing and are more rapid. A standardised method of detecting EGFR mutations needs to be established as soon as possible.

The final limitation in the present study is that it remains unclear whether there is any survival benefits associated with gefitinib therapy in those patients enrolled with EGFR mutations. The relationship between the EGFR mutation status determined in pleural effusion fluid and the gefitinib response in a portion of the patients enrolled supports the pleural effusion fluid EGFR mutation status as useful for predicting the response to gefitinib. The relationship between the EGFR mutation status determined in the pleural effusion fluid and the gefitinib response in the remaining patients and the survival benefit of gefitinib therapy in the patients with EGFR mutations are currently being evaluated, and confirmation of the results is expected in the very near future.

In conclusion, our results suggest that the DNA in pleural effusion fluid can be used to detect EGFR mutations and that the EGFR mutation status determined may be useful as a predictive factor of response to gefitinib.

\section{ACKNOWLEDGEMENTS}

We gratefully acknowledge the excellent statistical assistance of Tetsutaro Hamano. 


\section{REFERENCES}

Asano H, Toyooka S, Tokumo M, Ichimura K, Aoe K, Ito S, Tsukuda K, Ouchida M, Aoe M, Katayama H, Hiraki A, Sugi K, Kiura K, Date H, Shimizu N (2006) Detection of EGFR gene mutation in lung cancer by mutant-enriched polymerase chain reaction assay. Clin Cancer Res 12: $43-48$

Bosari S, Marchetti A, Buttitta F, Graziani D, Borsani G, Loda M, Bevilacqua G, Coggi G (1995) Detection of p53 mutations by single-strand conformation polymorphisms (SSCP) gel electrophoresis. A comparative study of radioactive and nonradioactive silver-stained SSCP analysis. Diagn Mol Pathol 4: 249-255

Breathnach OS, Freidlin B, Conley B, Green MR, Johnson DH, Gandara DR, O'Connell M, Shepherd FA, Johnson BE (2001) Twenty-two years of phase III trials for patients with advanced non-small-cell lung cancer: sobering results. J Clin Oncol 19: 1734-1742

Chernow B, Shahn SA (1997) Carcinomatous involvement of the pleura. Am J Med 63: 695-702

Fan X, Furnari FB, Cavenee WK, Castresana JS (2001) Non-isotopic silverstained SSCP is more sensitive than automated direct sequencing for the detection of PTEN mutations in a mixture of DNA extracted from normal and tumor cells. Int J Oncol 18: $1023-1026$

Fenton KN, David Richardson J (1995) Diagnosis and management of malignant pleural effusions. Am J Surg 170: 69-74

Franklin WA, Veve R, Hirsch FR, Helfrich BA, Bunn Jr PA (2002) Epidermal growth factor receptor family in lung cancer and premalignancy. Semin Oncol 29: 3 - 14

Fukuoka M, Yano S, Giaccone G, Tamura T, Nakagawa K, Douillard JY, Nishiwaki Y, Vansteenkiste J, Kudoh S, Rischin D, Eek R, Horai T, Noda K, Takata I, Smit E, Averbuch S, Macleod A, Feyereislova A, Dong RP, Baselga J (2003) Multi-institutional randomized phase II trial of gefitinib for previously treated patients with advanced nonsmall-cell lung cancer (The IDEAL 1 Trial) [corrected]. J Clin Oncol 21: $2237-2246$

Giaccone G, Herbst RS, Manegold C, Scagliotti G, Rosell R, Miller V, Natale RB, Schiller JH, Von Pawel J, Pluzanska A, Gatzemeier U, Grous J, Ochs JS, Averbuch SD, Wolf MK, Rennie P, Fandi A, Johnson DH (2004) Gefitinib in combination with gemcitabine and cisplatin in advanced non-small-cell lung cancer: a phase III trial - INTACT 1. J Clin Oncol 22: $777-784$

Han SW, Kim TY, Hwang PG, Jeong S, Kim J, Choi IS, Oh DY, Kim JH, Kim DW, Chung DH, Im SA, Kim YT, Lee JS, Heo DS, Bang YJ, Kim NK (2005) Predictive and prognostic impact of epidermal growth factor receptor mutation in non-small-cell lung cancer patients treated with gefitinib. J Clin Oncol 23: 2493-2501

Herbst RS, Giaccone G, Schiller JH, Natale RB, Miller V, Manegold C, Scagliotti G, Rosell R, Oliff I, Reeves JA, Wolf MK, Krebs AD, Averbuch SD, Ochs JS, Grous J, Fandi A, Johnson DH (2004) Gefitinib in combination with paclitaxel and carboplatin in advanced non-small-cell lung cancer: a phase III trial - INTACT 2. J Clin Oncol 22: $785-794$

Huang MJ, Lim KH, Tzen CY, Hsu HS, Yen Y, Huang BS (2005) EGFR mutations in malignant pleural effusion of non-small cell lung cancer: a case report. Lung Cancer 49: 413-415

Kelly K, Crowley J, Bunn Jr PA, Presant CA, Grevstad PK, Moinpour CM, Ramsey SD, Wozniak AJ, Weiss GR, Moore DF, Israel VK, Livingston RB, Gandara DR (2001) Randomized phase III trial of paclitaxel plus carboplatin versus vinorelbine plus cisplatin in the treatment of patients with advanced non-small-cell lung cancer: a Southwest Oncology Group trial. J Clin Oncol 19: 3210-3218

Kosaka T, Yatabe Y, Endoh H, Kuwano H, Takahashi T, Mitsudomi T (2004) Mutations of the epidermal growth factor receptor gene in lung cancer: biological and clinical implications. Cancer Res 64: 8919-8923
Lee JH, Hong YS, Ryu JS, Chang JH (2004) p53 and FHIT mutations and microsatellite alterations in malignancy-associated pleural effusion. Lung Cancer 44: $33-42$

Lynch TJ, Bell DW, Sordella R, Gurubhagavatula S, Okimoto RA, Brannigan BW, Harris PL, Haserlat SM, Supko JG, Haluska FG, Louis DN, Christiani DC, Settleman J, Haber DA (2004) Activating mutations in the epidermal growth factor receptor underlying responsiveness of non-small-cell lung cancer to gefitinib. $N$ Engl J Med 350: 2129-2139

Marchetti A, Martella C, Felicioni L, Barassi F, Salvatore S, Chella A, Camplese PP, Iarussi T, Mucilli F, Mezzetti A, Cuccurullo F, Sacco R, Buttitta F (2005) EGFR mutations in non-small-cell lung cancer: analysis of a large series of cases and development of a rapid and sensitive method for diagnostic screening with potential implications on pharmacologic treatment. J Clin Oncol 23: 857-865

Nakamoto M, Teramoto H, Matsumoto S, Igishi T, Shimizu E (2001) $\mathrm{K}-$ ras and rho A mutations in malignant pleural effusion. Int J Oncol 19: $971-976$

Paez JG, Janne PA, Lee JC, Tracy S, Greulich H, Gabriel S, Herman P, Kaye FJ, Lindeman N, Boggon TJ, Naoki K, Sasaki H, Fujii Y, Eck MJ, Sellers WR, Johnson BE, Meyerson M (2004) EGFR mutations in lung cancer: correlation with clinical response to gefitinib therapy. Science 304: $1497-1500$

Pao W, Miller V, Zakowski M, Doherty J, Politi K, Sarkaria I, Singh B, Heelan R, Rusch V, Fulton L, Mardis E, Kupfer D, Wilson R, Kris M, Varmus H (2004) EGF receptor gene mutations are common in lung cancers from \&quot;never smokers\&quot; and are associated with sensitivity of tumors to gefitinib and erlotinib. Proc Natl Acad Sci USA 101: $13306-13311$

Parkin DM, Bray F, Ferlay J, Pisani P (2005) Global cancer statistics, 2002. CA Cancer J Clin 55: 74-108

Pass HI, Johnson DH, Minna JD, Turrisi AT (2005) Lung cancer principles and practice. In Clinical Presentation of Non-Small Cell Carcinoma of the Lung Antoinette J, Wozniak, SMG (eds) pp 291-303. Philadelphia: Lippincott Williams \& Wilkins

Sasaki H, Endo K, Konishi A, Takada M, Kawahara M, Iuchi K, Matsumura A, Okumura M, Tanaka H, Kawaguchi T, Shimizu T, Takeuchi H, Yano M, Fukai I, Fujii Y (2005) EGFR Mutation status in Japanese lung cancer patients: genotyping analysis using Light Cycler. Clin Cancer Res 11: $2924-2929$

Schiller JH, Harrington D, Belani CP, Langer C, Sandler A, Krook J, Zhu J, Johnson DH, the Eastern Cooperative Oncology Group (2002) Comparison of four chemotherapy regimens for advanced non-small-cell lung cancer. $N$ Engl J Med 346: $92-98$

Takano T, Ohe Y, Sakamoto H, Tsuta K, Matsuno Y, Tateishi U, Yamamoto S, Nokihara H, Yamamoto N, Sekine I, Kunitoh H, Shibata T, Sakiyama $\mathrm{T}$, Yoshida T, Tamura T (2005) Epidermal growth factor receptor gene mutations and increased copy numbers predict gefitinib sensitivity in patients with recurrent non-small-cell lung cancer. J Clin Oncol 23: $6829-6837$

Therasse P, Arbuck SG, Eisenhauer EA, Wanders J, Kaplan RS, Rubinstein L, Verweij J, Van Glabbeke M, van Oosterom AT, Christian MC, Gwyther SG (2000) New guidelines to evaluate the response to treatment in solid tumors. European Organization for Research and Treatment of Cancer, National Cancer Institute of the United States, National Cancer Institute of Canada. J Natl Cancer Inst 92: 205-216

Travis W, Colbey TV, Corrin B (1999) Histologic Typing of Tumors of Lung and Pleura: World Health Organization International Classification of Tumors 3rd edn New York, NY: Springer Verlag

Wookey A, Ellison G, Donald E (2005) Comparison of methods for the detection of mutations in the epidermal growth actor receptor gene. In 96th Ann Meet Am Assoc Cancer Res 46: 1250, abstr. 5287 